\title{
Practice and thinking of modern clinical research of traditional Chinese medicine
}

Traditional Chinese medicine has a long history and plays an important role in the process of human health. In recent years, the clinical research of traditional Chinese medicine, including acupuncture and moxibustion, has been published in international famous journals. The charm of traditional Chinese medicine has also aroused great interest of patients and medical staff around the world. On October 1, 2018, the world health organization incorporated traditional Chinese medicine into its globally influential medical outline for the first time.

At the same time, scientific research and clinical trials related to traditional Chinese medicine have been further and widely carried out all over the world, accumulating a certain amount of high-quality evidence from a modern perspective for the clinical practice of traditional Chinese medicine. Is quantitative research, qualitative research or mixed research better? At present, there is no consensus that it is most suitable to explore the clinical scientific research methods of traditional Chinese medicine. However, we have been exploring in evaluating the efficacy of traditional Chinese medicine.

This special series of traditional Chinese medicine efficacy evaluation in Annals of Palliative Medicine invites many scholars engaged in clinical and scientific research to focus on the theme of traditional Chinese medicine clinical research, combined with modern science and technology and traditional philosophical thinking, to evaluate the application of science in traditional Chinese medicine with examples, and to jointly write the latest research findings and insights.

Scholars from China and Bulgaria published a total of nine studies. Firstly, in the aspect of basic research, some scholars explored that Shenning decoction could inhibit $W n t / \beta$-catenin pathway affects the mechanism of epithelial mesenchymal transition in diabetic mice, and some scholars have discussed the role of exocrine in vascular calcification in chronic kidney disease. These papers further explore the evaluation of traditional Chinese medicine treatment and the mechanism of modern perspective.

At the same time, in terms of clinical research of traditional Chinese medicine, researchers reviewed the home care of palliative patients, discussed the evidence-based clinical research of traditional Chinese medicine, shared the protocol of clinical practice guidelines for the treatment of influenza with traditional Chinese medicine, and carried out bibliometric research based on the English literature of randomized control trials of traditional Chinese medicine published in 2010-2019. The authors have explored from the macro perspective or mixed research, so as to provide ideas for future research.

The increase in the number of high-quality clinical research evidence prompted researchers to carry out evidence-based systematic evaluation and meta-analysis. The authors discussed the role of traditional Chinese medicine in the treatment of menorrhagia, the role of traditional Chinese medicine in preventing recurrence and improving prognosis after lithotripsy, and the efficacy and safety of Huazhi Rougan granule in the treatment of nonalcoholic hepatitis. These papers provide highquality evidence-based evidence for the solution of clinical problems, and can be used as a reference for clinicians in decisionmaking.

All in all, the research of traditional Chinese medicine should not only learn from modern science and technology, but also maintain the characteristics of traditional Chinese medicine. From the perspective of mixed research, weighing quantitative and qualitative, we can embark on the road of efficacy evaluation suitable for traditional Chinese medicine.

\section{Acknowledgments}

Funding: None.

\section{Footnote}

Provenance and Peer Review: This article was commissioned by the editorial office, Annals of Palliative Medicine for the series "Narrative \& Evidence-based Medicine for Traditional Medicine: from basic research to clinical practice and trial". The article did not undergo external peer review. 
Conflicts of Interest: Both authors have completed the ICMJE uniform disclosure form (available at https://dx.doi.org/10.21037/ apm-21-2634). The series "Narrative \& Evidence-based Medicine for Traditional Medicine: from basic research to clinical practice and trial" was commissioned by the editorial office without any funding sponsorship. BL and LDT served as the unpaid Guest Editors of the series. The authors have no other conflicts of interest to declare.

Ethical Statement: The authors are accountable for all aspects of the work in ensuring that questions related to the accuracy or integrity of any part of the work are appropriately investigated and resolved.

Open Access Statement: This is an Open Access article distributed in accordance with the Creative Commons AttributionNonCommercial-NoDerivs 4.0 International License (CC BY-NC-ND 4.0), which permits the non-commercial replication and distribution of the article with the strict proviso that no changes or edits are made and the original work is properly cited (including links to both the formal publication through the relevant DOI and the license). See: https://creativecommons.org/licenses/by-nc$\mathrm{nd} / 4.0 /$.

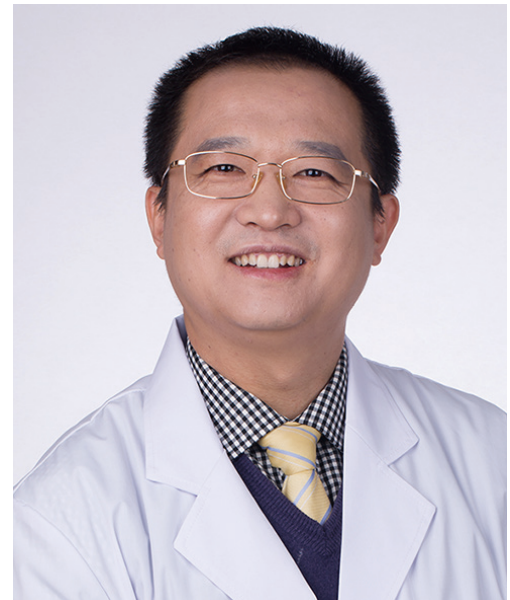

Bo Li

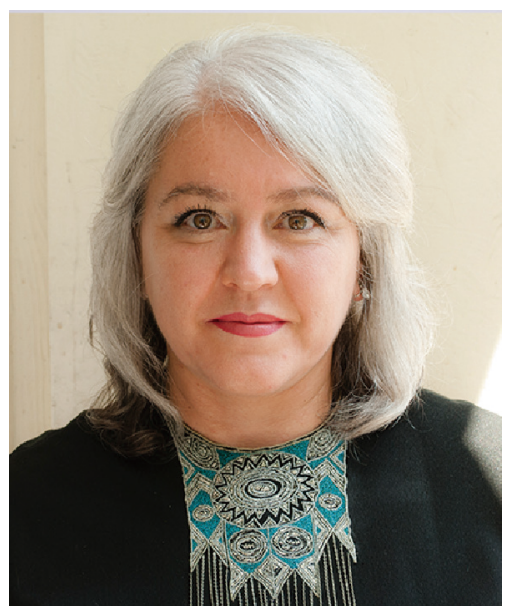

Lyubima Despotova-Toleva

Bo Li

Department of Evidence-Based Medicine Center, Beïing Hospital of Traditional Chinese Medicine, Capital Medical University/Beijing Institute of Traditional Chinese Medicine/Beijing Evidence-Based Chinese Medicine Center, Beïing, China. (Email: libo@bjzhongyi.com)

Lyubima Despotova-Toleva Medical Faculty, Medical University Plovdiv, Plovdiv, Bulgaria.

(Email:desptol@abv.bg)

Submitted Sep 15, 2021. Accepted for publication Oct 08, 2021. doi: 10.21037/apm-21-2634

View this article at: http://dx.doi.org/10.21037/apm-21-2634

Cite this article as: Li B, Despotova-Toleva L. Practice and thinking of modern clinical research of traditional Chinese medicine. Ann Palliat Med 2021;10(12):12919-12920. doi: 10.21037/apm-21-2634 